
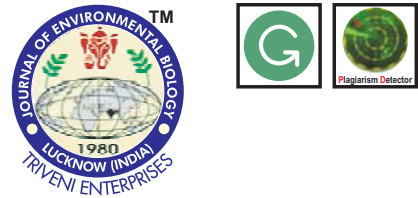

DOI : http://doi.org/10.22438/jeb/38/6/MRN-439
Journal of Environmental Biology

ISSN: 0254-8704 (Print) ISSN: 2394-0379 (Online) CODEN: JEBIDP

\title{
Evaluation of novel insecticides against diamondback moth and natural enemies in cabbage ecosystem
}

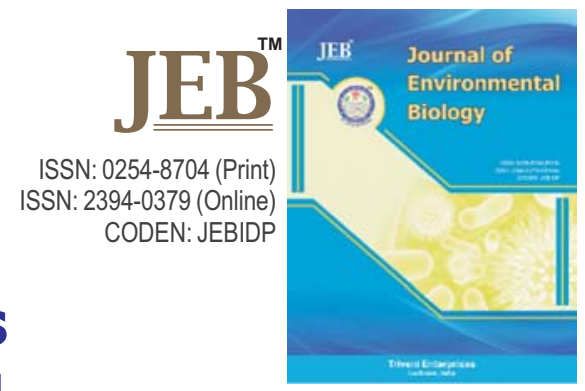

Authors Info

S. Patra*, V.W. Dhote ${ }^{2}$, S. Sarkar ${ }^{3}$ and A. Samanta ${ }^{2}$

'Division of Crop Protection, ICAR Research Complex for NEH Region, Umiam-793 103, India

${ }^{2}$ Department of Agricultural Entomology, Bidhan Chandra Krishi Viswavidyalaya, Nadia-741 252, India

${ }^{3}$ Krishi Vigyan Kendra, Uttar Banga Krishi Viswavidyalaya, Coochbehar-736 165, India

*Corresponding Author Email : sandippatra47@gmail.com

Key words

Cabbage ecosystem

Chlorfenapyr

Diamondback moth

Indoxacarb

Pyridalyl

Publication Info

Paper received : 14.10 .2016

Revised received : 28.12.2016

Re-revised received : 13.02 .2017

Accepted : 09.03.2017

\begin{abstract}
Aim: Insect pest infestation is the major limiting factors for commercial cultivation of cabbage. Diamondback moth (DBM) is the most notorious insect pest responsible for yield loss of cabbage in most of the cases. The objective of the present study was to evaluate some new insecticides having different novel mode of action against this pest.

Methodology: Field experiments were conducted at C-Block Farm, Bidhan Chandra Krishi Viswavidyalaya (BCKV), West Bengal, India during 2011-12 to 2013-14. The field experiments were laid out in randomized block design comprising eight treatments including control with three replications. The treatments viz. pyridalyl $10 \mathrm{EC}$, indoxacarb $14.5 \mathrm{SC}$, chlorfenapyr $10 \mathrm{SC}$ and chlorpyriphos $20 \mathrm{EC}$ were applied twice at fifteen days interval. Pre-treatment counts of DBM larvae were recorded from randomly selected 5 tagged plants/plot, and subsequently post treatment observations were recorded on 1,7 and 14 days after each spraying. Coccinellid complex and spiders were recorded during each observation after spraying. Healthy cabbages (weight basis) were recorded separately from each replication for yield data.
\end{abstract}

Results: Chlorfenapyr @ $200 \mathrm{~g}$ a.i. ha ${ }^{-1}$ was effective in reducing mean larval population of diamondback moth (1.21 larvae per plant) with $85.81 \%$ reduction over untreated control. Next best treatment was pyridalyl @ $150 \mathrm{~g}$ a.i. ha ${ }^{-1}$ with $82.71 \%$ reduction followed by indoxacarb @ $150 \mathrm{~g}$ a.i. ha ${ }^{-1}(78.44 \%$ reduction). Recommended doses of pyridalyl (75 g a.i. ha $\left.{ }^{-1}\right)$, indoxacarb (75 $\mathrm{g}$ a.i. ha ${ }^{-1}$ ) and chlorfenapyr (100 g a.i. ha ${ }^{-1}$ ) were also found to be effective treatments in reducing the larval population of diamondback moth. Highest costbenefit ratio $(1: 10.94)$ was recorded in pyrid a I y I a t recommended dose $(75$ $g$ a.i. ha ${ }^{-1}$ ) followed by chlorpyriphos@250 g a.i. ha $^{-1}(1: 10.90)$.

Interpretation: Chlorfenapyr, pyridalyl and indoxacrb were found to be effective insecticides against diamondback moth. Pyridalyl and indoxacarb were found to be relatively safe insecticides towards coccinellid beetles and spider population in cabbage ecosystem.

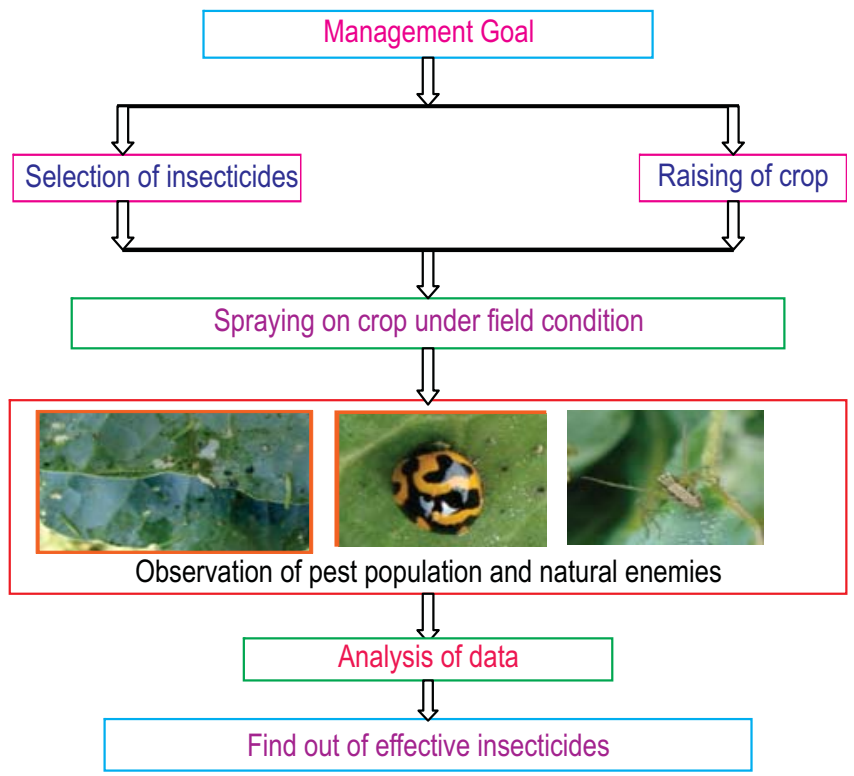




\section{Introduction}

Cabbage (Brassica oleraceae var. capitata Linn.) is a major winter vegetable grown all over India. In India, the area under cabbage cultivation was 4.00 lakh hectare and production of 90.39 lakh tonnes with an average productivity of $22.6 \mathrm{MT} \mathrm{ha}^{-1}$, as well as $5.5 \%$ share to the total national vegetable production during 2013-14 (NHB, 2015). Insect pest infestation is the major limiting factors for commercial cultivation of cabbage. Diamondback moth (Plutella xylostella L.), web worm ( Hellula undalis Fab.), cabbage butterflies (Pieris brassicae L.), cabbage head caterpillar (Crocidolomia binotalis Zeller), aphid ( Liphapis erysimi Kalt.) and flea beetle (Phyllotreta spp) attack the crop regularly. Among them, diamondback moth (DBM) is the most notorious pest which is responsible for yield loss of this crop in most of the cases. The problem is acute in areas where vegetables are grown extensively throughout the year (Joia et al., 2005). In India, Krishnamoorthy (2004) reported a $52 \%$ yield loss on cabbage due to diamondback moth (DBM), whereas Lingappa et al. (2006) reported that the yield loss caused by this pest varied from $31-100 \%$. The overall management cost for diamondback moth is estimated at US $\$ 4-5$ billion annually (Zalucki et al., 2012). To control this pest, insecticides have been used indiscriminately, resulting it has developed resistance to every synthetic insecticides used against it in the field (Telkar et al., 1990). In India, the first report of insecticide resistance development in the diamondback moth was in 1966 around Ludhiana, Punjab, against DDT and Parathion (Verma and Sandhu, 1968). After that the moth has developed resistance to about 82 compounds belonging to different classes of insecticides and in 17 countries (Furlong et al., 2013). In view of the above, the present study was undertaken to evaluate some new insecticides having different novel mode of action against this pest.

\section{Materials and Methods}

Field experiments were conducted at C-Block Farm, Bidhan Chandra Krishi Viswavidyalaya (BCKV), Kalyani, Nadia $\left(22^{\circ} 58^{\prime} 60 \mathrm{~N}\right.$ latitude, $88^{\circ} 28^{\prime} 60 \mathrm{E}$ longitude and at an altitude of $9.75 \mathrm{~m}$ from MSL), West Bengal, India to evaluate the bio-efficacy of some new insecticides against larvae of diamondback moth on cabbage during 2011-12 to 2013-14. Field trials were conducted on medium high land with sandy loam soil having almost neutral $\mathrm{pH}$. The climatic condition of the experimental site was typical to new alluvial zone of West Bengal. The field experiments were laid out in randomized block design (RBD) comprising eight treatments including control (T8) with three replications. The treatments viz. pyridalyl $10 \mathrm{EC}\{75$ (T1) and 150 (T2) g a.i./ha\}, indoxacarb 14.5SC $\left\{75\right.$ (T3) and 150 (T4) g a.i. ha $\left.{ }^{-1}\right\}$, chlorfenapyr 10 SC $\{100$ (T5) and 200 (T6) g a.i. ha" $\}$ and chlorpyriphos 20 EC $\{250$ (T7) g a.i. ha' $\}$ were sprayed when pest attained ETL level of 2 larvae/plant (Uthamasamy et al., 2011). First spray was applied at 40 days after transplanting and repeated after 15 days of first spray. Insecticides were applied with pneumatic knapsack sprayer using spray volume @ 500 litres ha ${ }^{-1}$. Pre-treatment observation was recorded by counting of diamond black moth larvae from randomly selected 5 tagged plants per plot one day before, and subsequently post treatment observations were recorded on 1, 7 and 14 days after each spray. Coccinellid complex and spiders were recorded during each observation after spraying. Healthy cabbages (weight basis) were recorded separately from each replicated plot at the time of harvest for calculation of yield and cost-benefit ratio. Cost-benefit ratio was calculated based on the market price of insecticides, wages for spraying, market price of produce at the time of experiments. The data on pest and natural enemy's population were transformed into square root values $\{\sqrt{ }(X+0.5)\}$ and then Duncan Multiple Test Range (DMRT) was done to compare the mean using SPSS 17.0 version.

\section{Results and Discussion}

The effectiveness of insecticides against larval population of diamondback moth (DBM) is depicted in Table 1. During first year, it was noted that there was a significant difference among the treatments in reducing the population of DBM in cabbage. Minimum mean larval population was recorded in double dose of chlorfenapyr (1.26 larvae per plant) treated plots followed by pyridalyl @ $150 \mathrm{~g}$ a.i. ha- treated plots with 1.27 larvae per plant. Recommended doses of insecticides revealed that pyridalyl was effective treatment against target pest with1.89 larvae per plant followed by chlorfenapyr (2.14 larvae per plant) and indoxacarb (2.64 larvae per plant). The conventional insecticide, chlorpyriphos was not much effective as newer insecticides but significantly superior over untreated control plots (9.74 larvae per plant). During second and third year of experiments, significant differences were noted among the treatments and all the treatments were found to be effective against the larvae of diamondback moth. The efficacy of the insecticides during second and third years showed similar trend that was found in first year experiment. Cumulative mean larvae was lowest in chlorfenapyr @150 g a.i. ha ${ }^{-1}$ treated plots (1.21 larvae per plant) followed by pyridalyl @150 g a.i. ha ${ }^{-1}$ (1.47 larvae per plant) and indoxacarb @150 g a.i. ha ${ }^{-1}$ (1.83 larvae per plant). In case of recommended doses, lowest number of larvae (2.00 larvae per plant) was recorded in pyridalyl treated plots which was at par with chlorfenapyr (2.07 larvae per plant) and indoxacarb (2.59 larvae per plant). Chlorpyriphos treated plots recoded relatively higher number of larvae (2.80 larvae per plant), but it was statistically significant over untreated control plots (8.50 larvae per plant). In the present experiment, chlorfenapyr was effective insecticide against diamond back moth. It is a pyrrole group of insecticide having insecticide-miticide properties. It acts as pro-insecticide on the mitochondria which disrupt ATP production thereby causing cellular death and organism mortality. The results of the present study may be corroborated with the findings of Zhang et al. (2001) who reported that $3^{\text {td }}$ instar larvae of 
Table 1: Efficacy of insecticides against larvae of diamondback moth (DBM) during 2011-12 to 2013-14

\begin{tabular}{|c|c|c|c|c|c|c|c|c|c|}
\hline \multirow[t]{3}{*}{ Treatments } & \multirow{3}{*}{$\begin{array}{l}\text { Dose } \\
(\text { ga.i. ha') }\end{array}$} & \multicolumn{6}{|c|}{ Number of DBM larvae/plant during consecutive years } & \multirow{3}{*}{$\begin{array}{l}\text { Cumulative } \\
\text { number of } \\
\text { larvae/plant } \\
\text { (Pooled } \\
\text { mean士SEM) }\end{array}$} & \multirow{3}{*}{$\begin{array}{l}\text { Reduction } \\
\text { over } \\
\text { control } \\
(\%)\end{array}$} \\
\hline & & \multicolumn{2}{|c|}{ 2011-12 } & \multicolumn{2}{|c|}{ 2012-13 } & \multicolumn{2}{|c|}{ 2013-14 } & & \\
\hline & & Before spray & $\begin{array}{l}\text { Mean of two } \\
\text { spray } \pm S E M\end{array}$ & Before spray & $\begin{array}{l}\text { Mean of two } \\
\text { spray } \pm \text { SEM }\end{array}$ & Before spray & $\begin{array}{l}\text { Mean of two } \\
\text { spray } \pm \text { SEM }\end{array}$ & & \\
\hline Pyridalyl 10EC & 75 & $\begin{array}{l}5.00 \pm 0.577 \\
(2.35)^{\mathrm{a}}\end{array}$ & $\begin{array}{l}1.89 \pm 0.157 \\
(1.53)^{\mathrm{ab}}\end{array}$ & $\begin{array}{l}4.45 \pm 0.400 \\
(2.22)^{\mathrm{a}}\end{array}$ & $\begin{array}{l}2.54 \pm 0.084 \\
(1.74)^{\mathrm{ab}}\end{array}$ & $\begin{array}{l}4.00 \pm 1.000 \\
(2.12)^{\mathrm{a}}\end{array}$ & $\begin{array}{l}1.57 \pm 0.041 \\
(1.44)^{\mathrm{bc}}\end{array}$ & $\begin{array}{l}2.00 \pm 0.064 \\
(1.62)^{\mathrm{bc}}\end{array}$ & 76.48 \\
\hline Pyridalyl 10EC & 150 & $\begin{array}{l}8.00 \pm 1.527 \\
(2.92)^{a}\end{array}$ & $\begin{array}{l}1.27 \pm 0.131 \\
(1.32)^{\mathrm{a}}\end{array}$ & $\begin{array}{l}4.11 \pm 1.681 \\
(2.15)^{\mathrm{a}}\end{array}$ & $\begin{array}{l}2.00 \pm 0.147 \\
(1.57)^{\mathrm{a}}\end{array}$ & $\begin{array}{l}3.67 \pm 0.881 \\
(2.04)^{a}\end{array}$ & $\begin{array}{l}1.14 \pm 0.062 \\
(1.28)^{\mathrm{ab}}\end{array}$ & $\begin{array}{l}1.47 \pm 0.069 \\
(1.46)^{\mathrm{ab}}\end{array}$ & 82.71 \\
\hline Indoxacarb 14.5SC & 75 & $\begin{array}{l}5.33 \pm 1.452 \\
(2.42)^{\mathrm{a}}\end{array}$ & $\begin{array}{l}2.64 \pm 0.007 \\
(1.77)^{\mathrm{b}}\end{array}$ & $\begin{array}{l}5.11 \pm 2.188 \\
(2.37)^{\mathrm{a}}\end{array}$ & $\begin{array}{l}3.30 \pm 0.089 \\
(1.94)^{b}\end{array}$ & $\begin{array}{l}3.47 \pm 0.352 \\
(1.99)^{\mathrm{a}}\end{array}$ & $\begin{array}{l}1.84 \pm 0.035 \\
(1.53)^{c}\end{array}$ & $\begin{array}{l}2.59 \pm 0.066 \\
(1.76)^{\mathrm{bc}}\end{array}$ & 69.50 \\
\hline Indoxacarb 14.5SC & 150 & $\begin{array}{l}5.67 \pm 0.881 \\
(2.48)^{\mathrm{a}}\end{array}$ & $\begin{array}{l}1.92 \pm 0.018 \\
(1.56)^{\mathrm{ab}}\end{array}$ & $\begin{array}{l}4.44 \pm 0.294 \\
(2.22)^{\mathrm{a}}\end{array}$ & $\begin{array}{l}2.31 \pm 0.106 \\
(1.67)^{\mathrm{ab}}\end{array}$ & $\begin{array}{l}2.47 \pm 0.176 \\
(1.72)^{a}\end{array}$ & $\begin{array}{l}1.27 \pm 0.045 \\
(1.32)^{\mathrm{abc}}\end{array}$ & $\begin{array}{l}1.83 \pm 0.038 \\
(1.53)^{\text {abc }}\end{array}$ & 78.44 \\
\hline Chlorfenapyr 10SC & 100 & $\begin{array}{l}5.00 \pm 0.577 \\
(2.35)^{\mathrm{a}}\end{array}$ & $\begin{array}{l}2.14 \pm 0.113 \\
(1.62)^{\mathrm{ab}}\end{array}$ & $\begin{array}{l}5.00 \pm 1.261 \\
(2.35)^{\mathrm{a}}\end{array}$ & $\begin{array}{l}2.48 \pm 0.116 \\
(1.72)^{\mathrm{ab}}\end{array}$ & $\begin{array}{l}4.73 \pm 0.581 \\
(2.29)^{a}\end{array}$ & $\begin{array}{l}1.59 \pm 0.095 \\
(1.44)^{b c}\end{array}$ & $\begin{array}{l}2.07 \pm 0.098 \\
(1.59)^{\mathrm{bc}}\end{array}$ & 75.66 \\
\hline Chlorfenapyr 10SC & 200 & $\begin{array}{l}5.67 \pm 1.333 \\
(2.48)^{\mathrm{a}}\end{array}$ & $\begin{array}{l}1.26 \pm 0.092 \\
(1.32)^{\mathrm{a}}\end{array}$ & $\begin{array}{l}4.33 \pm 1.333 \\
(2.20)^{\mathrm{a}}\end{array}$ & $\begin{array}{l}1.56 \pm 0.064 \\
(1.43)^{\mathrm{a}}\end{array}$ & $\begin{array}{l}4.20 \pm 0.503 \\
(2.17)^{\mathrm{a}}\end{array}$ & $\begin{array}{l}0.80 \pm 0.100 \\
(1.13)^{\mathrm{a}}\end{array}$ & $\begin{array}{l}1.21 \pm 0.107 \\
(1.30)^{\mathrm{a}}\end{array}$ & 85.81 \\
\hline Chlorpyriphos 20EC & 250 & $\begin{array}{l}6.00 \pm 1.154 \\
(2.55)^{\mathrm{a}}\end{array}$ & $\begin{array}{l}3.23 \pm 0.145 \\
(1.92)^{b}\end{array}$ & $\begin{array}{l}5.22 \pm 0.618 \\
(2.39)^{\mathrm{a}}\end{array}$ & $\begin{array}{l}3.22 \pm 0.050 \\
(1.93)^{b}\end{array}$ & $\begin{array}{l}4.20 \pm 0.305 \\
(2.14)^{\mathrm{a}}\end{array}$ & $\begin{array}{l}1.94 \pm 0.124 \\
(1.55)^{c}\end{array}$ & $\begin{array}{l}2.80 \pm 0.061 \\
(1.82)^{c}\end{array}$ & 67.11 \\
\hline Control & - & $\begin{array}{l}6.00 \pm 1.527 \\
(2.55)^{\mathrm{a}}\end{array}$ & $\begin{array}{l}9.74 \pm 0.214 \\
(3.19)^{c}\end{array}$ & $\begin{array}{l}5.67 \pm 1.574 \\
(2.48)^{\mathrm{a}}\end{array}$ & $\begin{array}{l}11.31 \pm 0.126 \\
(3.43)^{c}\end{array}$ & $\begin{array}{l}3.73 \pm 0.405 \\
(2.06)^{\mathrm{a}}\end{array}$ & $\begin{array}{l}4.46 \pm 0.015 \\
(2.23)^{d}\end{array}$ & $\begin{array}{l}8.50 \pm 0.156 \\
(2.99)^{d}\end{array}$ & \\
\hline
\end{tabular}

Difference in mean values was determined by DMRT. Mean sharing the same letters in a column are not significantly different at $5 \%$ level of significance; Data in parentheses are square root transformed values

Table 2 : Economics of insecticidal management of major pest of cabbage during 2011-12 to 2013-14 (Pooled of three seasons)

\begin{tabular}{|c|c|c|c|c|c|c|c|c|c|}
\hline Treatments & $\begin{array}{l}{ }^{*} \text { Cost of } \\
\text { insecticides } \\
\text { (Rs per L } \\
\text { or Kg) }\end{array}$ & $\begin{array}{l}\text { Dose } \\
\left(\text { ga.i. ha }{ }^{-1}\right)\end{array}$ & $\begin{array}{l}\text { Total quantity } \\
\text { of insecticides } \\
\text { required } \\
\left(\text { L or Kg ha }^{-1}\right)\end{array}$ & $\begin{array}{l}\text { Cost for } \\
\text { insecticides } \\
\left(\text { Rs ha }^{-1}\right)\end{array}$ & $\begin{array}{l}\text { *Labour } \\
\text { cost for two } \\
\text { spraying } \\
\text { (Rs ha') }\end{array}$ & $\begin{array}{l}\text { Total cost } \\
\text { of protection } \\
\left(\mathrm{Rs} \mathrm{ha}^{-1}\right)\end{array}$ & $\begin{array}{l}{ }^{*} \text { Net yield } \\
\text { gain over } \\
\text { control } \\
\left(\mathrm{t} \mathrm{ha}^{-1}\right)\end{array}$ & $\begin{array}{l}\text { Profit } \\
\text { over } \\
\text { control } \\
\text { (Rs ha' }^{-1} \text { ) }\end{array}$ & $\begin{array}{l}\text { Cost - } \\
\text { benefit- } \\
\text { ratio (C:B) }\end{array}$ \\
\hline Pyridalyl 10EC & 2633.33 & 75 & 0.750 & 1975.00 & 1700 & 3675.00 & 20.11 & 40221 & $1: 10.94$ \\
\hline Pyridalyl 10EC & 2633.33 & 150 & 1.500 & 3950.00 & 1700 & 5650.00 & 26.65 & 53293 & $1: 9.11$ \\
\hline Indoxacarb 14.5SC & 4366.67 & 75 & 0.517 & 2257.56 & 1700 & 3957.57 & 19.63 & 39265 & $1: 9.92$ \\
\hline Indoxacarb 14.5SC & 4366.67 & 150 & 1.034 & 4515.13 & 1700 & 6215.13 & 25.74 & 51476 & $1: 8.64$ \\
\hline Chlorfenapyr 10SC & 2533.33 & 100 & 1.000 & 2533.33 & 1700 & 4233.33 & 20.44 & 40889 & $1: 9.66$ \\
\hline Chlorfenapyr 10SC & 2533.33 & 200 & 2.000 & 5066.66 & 1700 & 6766.67 & 26.84 & 53689 & $1: 7.88$ \\
\hline Chlorpyrifos 20EC & 416.67 & 250 & 1.250 & 520.83 & 1700 & 2220.83 & 12.10 & 24202 & $1: 10.90$ \\
\hline
\end{tabular}

N.B.: Labour/ha/spray $=5$, Wages $=$ Rs $170 /$ - per day, Rate of cabbage $=$ Rs 2 per kg, ${ }^{*}$ Average of three years

DBM treated with chlorfenapyr showed $100 \%$ mortality after 2 days of treatment indicating that this insecticide had better control effects on field resistant population from China. Satpathy et al. (2005) reported that chlorfenapyr @ 75 and $100 \mathrm{~g}$ a.i. ha ${ }^{-1}$ was most effective against DBM, whereas Choudhary et al. (2014) showed that chlorfenapyr was less effective as compared to UPI 106 and novaluron against $P$. xylostella and $S$. litura on cabbage. The present results are in conformity with the findings of Chatterjee and Mondal (2012) who reported the effectiveness of chlorfenapyr in reducing the damage caused by DBM on cabbage. Pyridalyl was the next best treatment against diamondback moth in the present study. It is a new active substance which is currently not allocated to any class of insecticides. Its biochemical mode of action is not fully elucidated. It acts by contact and ingestion and shows cytotoxicity to cells of lepidopterous insects (EFSA, 2009). Sakamoto et al. (2004) reported that pyridalyl gave good control of various lepidopterous and thysanopterous pests on cotton and vegetables, without any phytotoxicity. It controls population of Helicoverpa virescens $F$ and $P$. xylostella $(\mathrm{L})$ which are resistant to various currently used insecticides. Very few works has been done with this insecticide against target pest of cabbage under Indian condition. Suganthi et al. (2007) reported that pyridalyl 10 EC @ 75 and $100 \mathrm{~g}$ a.i. ha ${ }^{-1}$ was effective against DBM on cabbage as well as registered 


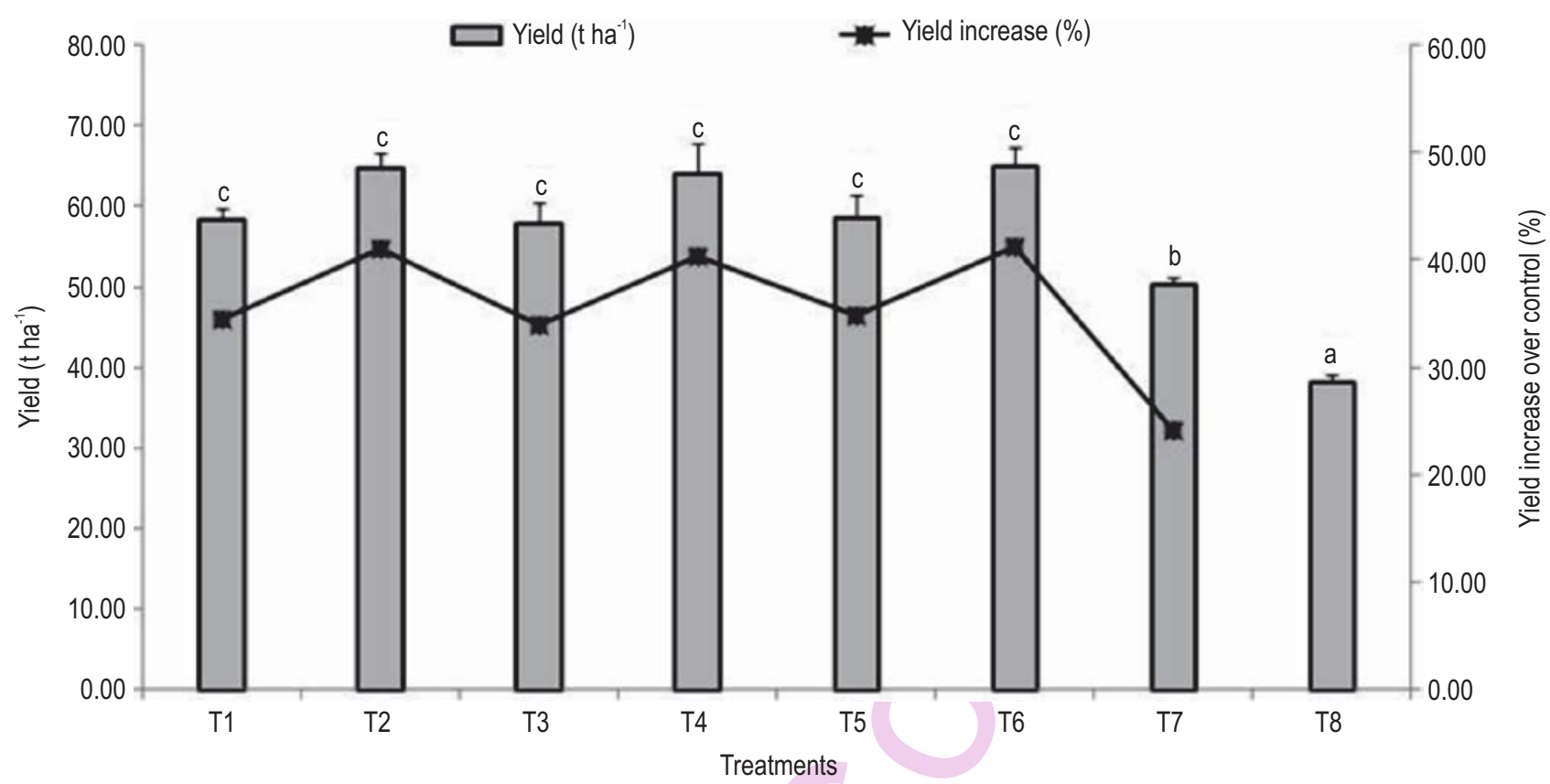

Fig. 1 : Effect of insecticides on yield of cabbage. Difference in mean values was determined by DMRT. Mean sharing same letters in a graph are not significantly different at $5 \%$ level of significance

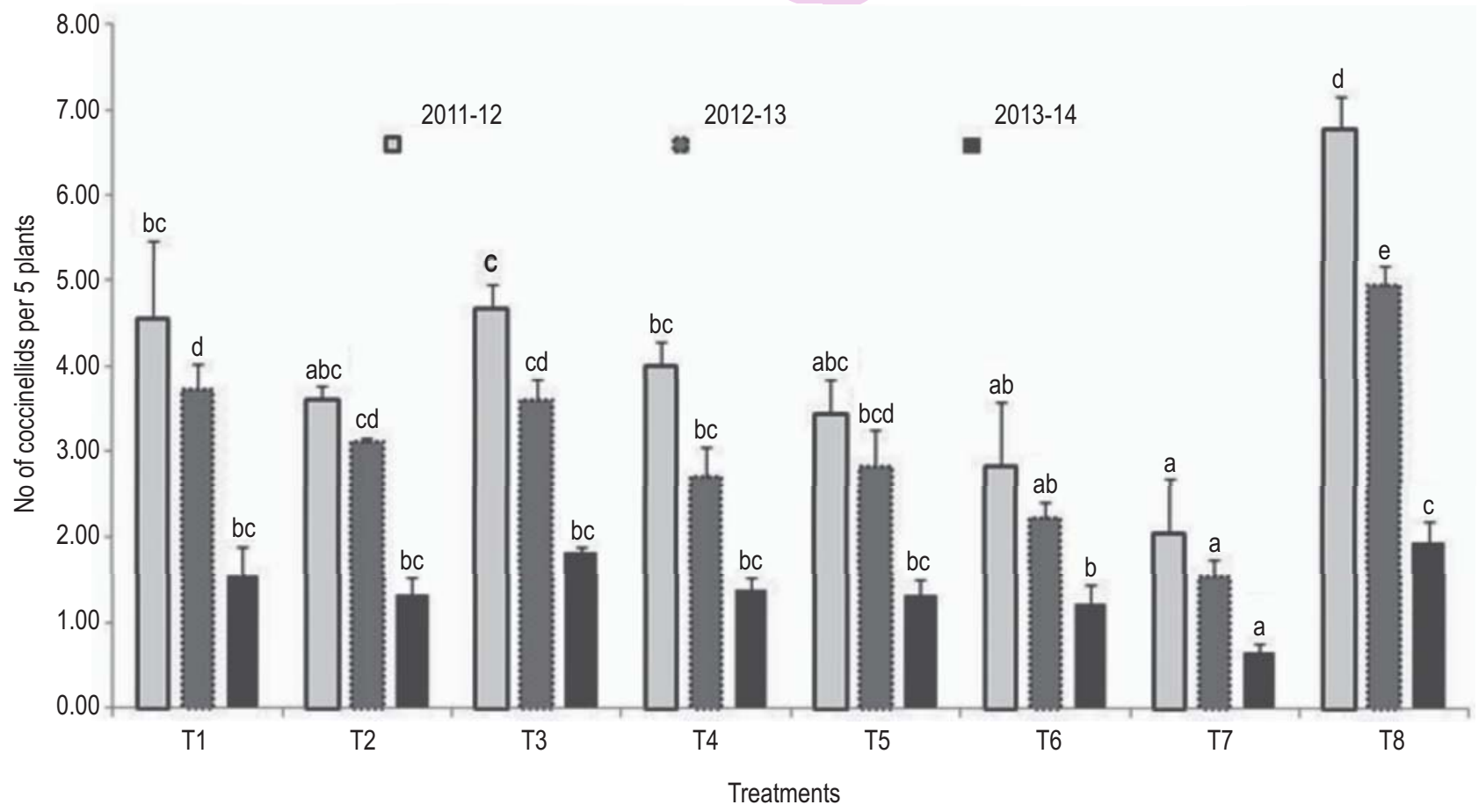

Fig. 2 : Effect of insecticides on coccinellid beetles. Difference in mean values was determined by DMRT. Mean sharing same letters in a respective bar are not significantly different at $5 \%$ level of significance

significantly higher yields as compared to other treatments. These findings are in agreement with Chakraborty and Somchoudhury (2011) who reported 25,50 and $75 \mathrm{~g}$ a.i. ha ${ }^{-1}$ pyridalyl was effective against DBM up to 15 days after spraying.
High efficacy of pyridalyl was also reported against pod borer complex of red gram (Karmakar and Patra, 2015). Indoxacarb is a member of new oxadiazine class of insecticides that act by inhibiting sodium ion entry in nerve cells, resulting in the paralysis 


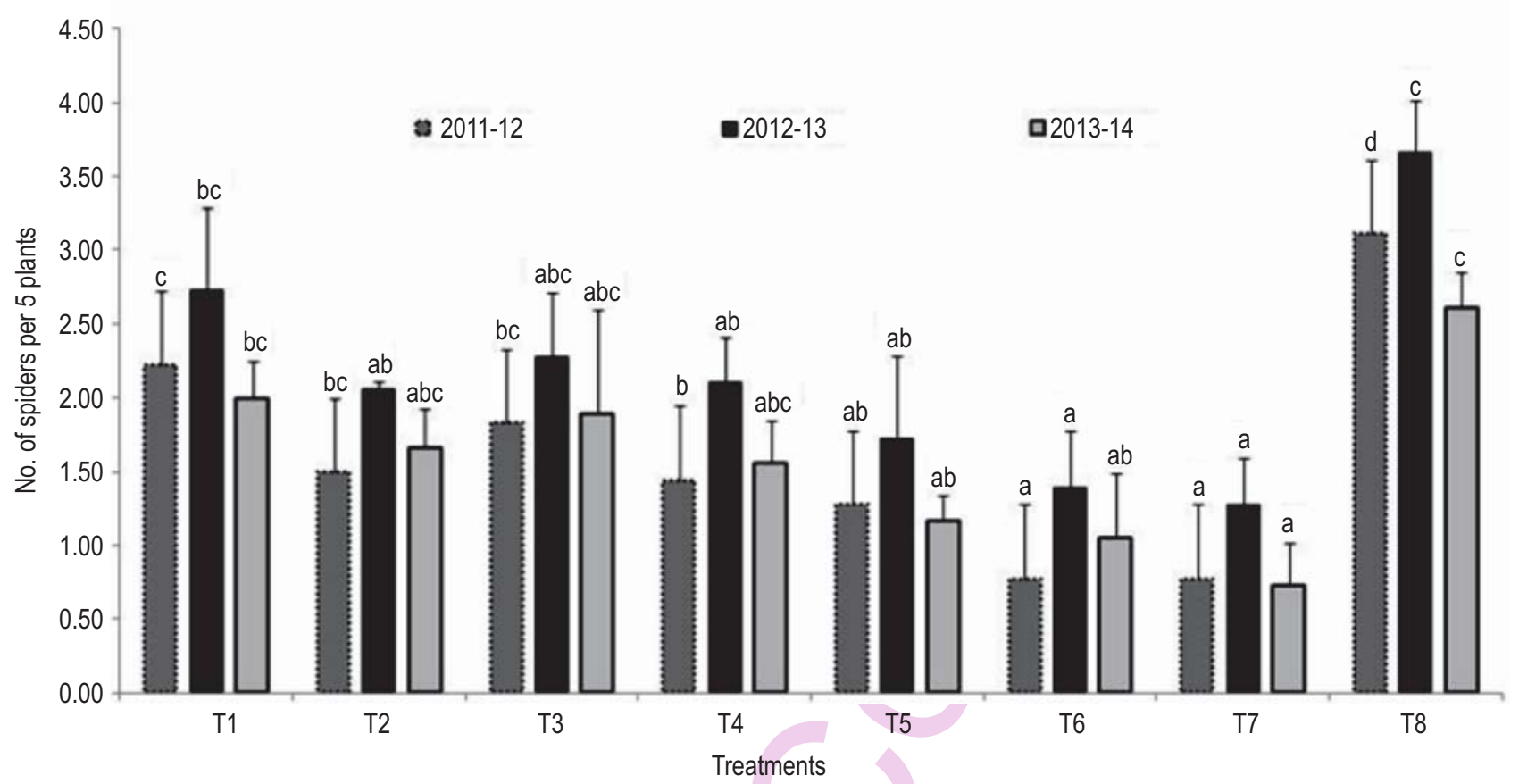

Fig. 3 : Effect of insecticides on spiders. Difference in mean values was determined by DMRT. Mean sharing same letters in a respective bar are not significantly different at $5 \%$ level of significance

and death of target insect pests. Effectiveness of indoxacarb against DBM in cabbage has earlier been reported (Liu et al., 2003; Gupta et al., 2008 and Vaseem et al., 2014). The present results are in conformity with Kumar and Meena (2010) who reported that indoxacarb @ $75 \mathrm{~g}$ a.i. ha ${ }^{-1}$ was the most effective treatment against $P$. xylostella. Joia et al. (2003) reported high toxicity and the potential use of indoxacarb against multi-resistant populations, $P$. xylostella based on $\mathrm{LC}_{50}$ value. In the present findings, chlorpyriphos showed relatively low efficacy which may be due to the development of resistance against this insecticide (Sontakke et al., 2016). Presence of bacterial communities in the gut of diamondback moth may confer the insecticides resistance. Degradation of acephate by Enterobactor asburiae, Bacillus cereus and Pantoea agglomerans isolated from diamondback moth Plutella xylostella may play a role in the development of insecticide resistance (Ramya et al., 2016).

Cumulative marketable yield of cabbage and economics of pest management is presented in Fig. 1 and Table 2. Highest marketable yield was recorded in chlorfenapyr @ $200 \mathrm{~g}$ a.i. ha ${ }^{-1}$ treated plots ( $\left.65.90 \mathrm{t} \mathrm{ha}^{-1}\right)$ followed by pyridalyl @ $150 \mathrm{~g}$ a.i. ha ${ }^{-1}$ $\left(65.71\right.$ tha $\left.^{-1}\right)$. There was no significance differences between two (recommended and double the recommended) doses of pyridalyl, indoxacarb and chlorfenapyr against yield of cabbage (Fig. 1). Among the insecticidal treatments, chlorpyriphos recorded lowest yield (51.16 tha $\left.{ }^{-1}\right)$, however it was significantly difference from control plots $\left(39.06 \mathrm{tha}^{-1}\right)$. Recommended doses of all insecticides were found to be effective in term of benefit-cost ratio. Among the recommended doses, highest benefit-cost ratio was recorded in pyridalyl (10.94) followed by chlorpyriphos (10.90), indoxacarb (9.92) and chlorfenapyr (9.66). To best of the knowledge, literatures on benefit-cost ratio for most of the insecticides were not found against target pest of cabbage; therefore, this study might be useful for selecting cost effective insecticides for the management of lepidopteran pests of cabbage. The present findings may be evaluated with related works on other crops with these insecticides. Conventional insecticide, chlorpyriphos showed high cost benefit ratio after pyridalyl; it may be due to low price of chlorpyriphos as compared to other insecticides. Jagadish et al. (2009) reported cost: benefit ratio of chlorpyriphos was 1:12.53 for the management of defoliators and capitulum borer of sunflower. Rudramuni et al. (2011) reported maximum cost: benefit ratio in methomyl (1:2.68) followed by chlorpyriphos + cypermethrin, profenofos + cypermethrin and indoxacarb in cotton. Karabhantanal and Awaknavar (2004) reported that indoxacarb had the highest expenditure and lowest cost: benefit ratio for management of tomato fruit borer, $H$. armigera.

Effect of insecticides on coccinellids population is presented in Fig. 2. In the year of 2011-12, Pyridalyl (75 $\mathrm{g}$ a.i. ha ${ }^{-1}$ ) and indoxacarb (75 g a.i. ha ${ }^{-1}$ ) were relatively less toxic towards coccinellids with 4.56 and 4.67 coccinellids per 5 plants, respectively, whereas in control plot it was 6.78 coccinellids per 5 plants. On the other hand, chlorfenapyr $\left(200 \mathrm{~g}\right.$ a.i. ha $\left.{ }^{-1}\right)$ and chlorpyriphos showed highly toxic effects to coccinellids. Similar trend were also observed during second and third years of experiments. Among the tested insecticides, chlorpyriphos was 
most toxic towards coccinellids followed by chlorfenapyr, whereas indoxacarb was moderately toxic and pyridalyl was less toxic against coccinellids. Literatures regarding toxic effects of these insecticides against coccinellid beetles are very scanty. Pyridalyl was less harmful than existing insecticides to various beneficial arthropods (Sakamoto et al., 2004 and Isayama et al., 2005). El-Khouly and Omar (2002) revealed that chlorfenapyr was moderately effective either in controlling the insect pest or in its side effect on the associated biological control agents, namely C. undecimpunctata, C. carnea and Paederus alfierii inhabiting sugarbeet fields, while Seal et al. (2006) reported that spinosad was slightly harmful and chlorfenapyr was moderately harmful to Cryptolaemus sp. predators in chilli ecosystem. Pedroso et al. (2011) also reported that chlorfenapyr, chlothianidin and imidacloprid/ beta-cyfluthrin were toxic to Cycloneda sanguinea pupae and adults. Adverse effect of chlorpyriphos on coccinellid beetles may be compared with findings of many workers (Pasqualini and Civolani, 2003; Ahmad et al., 2008 and ElHawary et al., 2010).

The impact of insecticides on spider population is depicted in Fig 3. Pyridalyl @ $75 \mathrm{~g}$ a.i. ha ${ }^{-1}$ showed higher spider populations with 2.22, 2.72 and 2.00 spiders per 5 plant as compared to others treatments during consecutive years, respectively. Minimum spider populations $(0.78,1.28$ and 0.72 spiders per 5 plants) were found to be recorded in chlorpyriphos treated plots followed by chlorfenapyr @ $200 \mathrm{~g}$ a.i. ha ${ }^{-1}$ during first, second and third year of experiments, respectively. Among the insecticides, chlorfenapyr at double dose and chlorpyriphos demonstrated highly toxic effects on spider population, while pyridalyl and indoxacarb were found to be relatively less toxic towards spider population. The effect of chlorpyriphos on spiders may be corroborated with Stark and Crawford (2005) and Seetharamu et al. (2006) who reported high toxicity of chlorpyriphos on spider species. High toxic effects of chlorpyriphos on spider population has been previously reported (Wang et al., 2009 and Mustafa et al., 2011). The results are in agreement with the study of Mahmoud et al. (2011) who reported that ChallengerReg. 36\% SC (Chlorofenapyr) caused the highest reduction of spider. Girish et al. (2012) also reported the negative effect of chlorfenapyr on spider population in rice. Mukherjee et al. (2011) reported that the predatory fauna namely ground beetle and spider were not significantly affected at different dosage of indoxacarb as compared to monocrotophos. Safeties of pyridalyl over existing insecticides to various beneficial arthropods has also been reported (Sakamoto et al., 2004 and Isayama et al., 2005).

In the present study, it was observed that chlorfenapyr was most effective treatment against larvae of diamondback moth followed by pyridalyl and indoxacarb. However, highest costbenefit ratio was recorded in pyridalyl at recommended dose followed by chlorpyriphos. Regarding safeties to natural enemies, chlorpyriphos and chlorfenapyr showed high toxicity towards coccinellid beetles and spider population. Considering efficacies, cost effectiveness as well as adverse effect on natural enemies, the present study conclude that pyridalyl may be recommended for effective management of diamondback moth with less adverse effect on natural enemies in cabbage crop.

\section{Acknowledgment}

First author is highly thankful to the Director, ICAR Research Complex for NEH Region, Umiam, Meghalaya for his encouragement and support to carry out this research.

\section{References}

Ahmad, M.M., S.B. Ahmad and A. Mudasir: Selectivity of few insecticides to adults of lady bird beetle, Coccinella septempunctata. Ind. J. PI. Prot., 36, 304-305 (2008).

Chakraborty, G. and A.K. Somchoudhury: Effect of pyridalyl against Plutella xylostella (L.) on cabbage and natural enemies. J. Crop Weed, 7, 142-145(2011).

Chatterjee, M.L. and S. Mondal: Sustainable management of key lepidopteran insect pests of vegetables. Acta Horticulturae, 958, 147-153 (2012).

Choudhary, R.K., P. Swathi, S. Upadhyay, S.B. Singh and M. Sharma: Efficacy of insect growth regulators against diamondback moth and tobacco caterpillar infesting cabbage crop. Annal. Pl. Soil Res., 16, 308-311 (2014).

EFSA: Setting of new MRLs for pyridalyl in tomatoes, aubergines (egg plants), peppers, cucurbits (inedible peel), lettuce and cotton seed. EFSA Scientific Report, 270, 1-21 (2009).

El-Hawary, F.M., E.A. Amr and N.A. Farag: Impact of some insecticides on the predator, Coccinella undecimpunctata L. (Coleoptera: Coccenillidae) and its prey, Brevicoryne brassicae L. (Homoptera: Aphididae) under laboratory conditions. Egyptian J. Biol. Pest Cont., 20, 149-153 (2010).

El-Khouly, M.I. and B.A. Omar: The efficiency of some insecticides on tortoise beetle, Cassida vittata Vill. inhabiting sugar beet fields. Egyptian J. Agricul. Res., 80, 697-708 (2002).

Furlong, M.J., D.J. Wright and L.M. Dosdall: Diamondback moth ecology and management: Problems, progress and prospects. Annu. Rev. Entomol., 58, 517-541 (2013).

Girish, V.P., H. Mahabaleshwar, R.S. Giraddi and K.B. Goud: Evaluation of newer insecticides and botanical against predatory spiders population in rice ecosystem. J. Exp. Zool., 15, 439-442 (2012).

Gupta, G.P., A. Birah and U.K. Shukla: Response of novel insecticides on diamondback moth, Plutella xylostella (L.). Ind. J. Ent., 70, 47-50 (2008).

Isayama, S., S. Saito, K. Kuroda, K. Umeda and K. Kasamatsu: Pyridalyl, a novel insecticide: Potency and insecticidal selectivity. Arch. Insect Bioch. Physiol., 58, 226-233 (2005).

Jagadish, K.S., Y.G. Shadakshari, K.N. Geetha, K. Karuna, K.T. Puttarangaswamy and T.K. Nagarathna: Efficacy of some new insecticide molecules against the defoliators and capitulum borer of sunflower. Pest Manag. Eco. Zool., 17, 39-46 (2009).

Joia, B.S., A.S. Udeaan, K.S. Suri, J. Kaur and S.K. Uberoi: Status of insecticide resistance in diamondback moth, Plutella xylostella (L.). Punjab J. Insect Sci., 18, 59-64 (2005). 
Joia, B.S., K.S. Suri and A.S. Udeaan: Baseline susceptibility of diamondback moth, Plutella xylostella (Linn.), to new insecticides. Resistant Pest Manag. Newsl., 12, 30-32 (2003).

Karabhantanal, S.S. and J.S. Awaknavar: Efficacy of some insecticides against the tomato fruit borer, Helicoverpa armigera (Hubner). Pest Manag. Eco. Zool., 12, 131-136 (2004).

Karmakar, K. and S. Patra: Bio-efficacy of some new insecticide molecules against pod borer complex of Red gram. Leg. Res., 38, 253-259 (2015).

Krishnamoorthy, A.: Biological control of diamondback moth Plutella xylostella (L.), an Indian scenario with reference to past and future strategies. In: Proceedings of the International Symposium (Eds.: A.A. Kirk and D. Bordat). Montpellier, France, CIRAD, pp. 204-211 (2004).

Kumar, A. and N.K. Meena: Field evaluation of indoxacarb 14.5\% SC against diamondback moth, Plutella xylostella linn. on cabbage and it's phytotoxicity. Pest Mang. Hort. Ecos., 16, 179-183 (2010).

Lingappa, S.K., K.A. Basavanagoud, R. Kulkarni, S. Patil and D.N. Kambrekar: Threat to vegetable production by diamondback moth and its management Strategies. Dis. Manag. Fruits Veget., 1, 357396 (2006).

Liu, T.X., A. N-Jr. Sparks and W. Chen: Toxicity, persistence and efficacy of indoxacarb and two other insecticides on Plutella xylostella (Lepidoptera: Plutellidae) immatures in cabbage. Inte. J. Pest Manag., 49, 235-241 (2003).

Mahmoud, M.F.R., A.A.R. Rahif and M.S.A. Mohammad: Impact of different pesticides on spider species of four families. Acarines, $\mathbf{5}$, 51-56 (2011).

Mukherjee, S.K., P.R. Mishra and D. Dash: Studies of new insecticide molecule Indoxacarb 15 EC against rice leaffolder, Cnaphalocrocis medinalis Guenee and yield. J. Pl. Protec. Env., 8, 35-38 (2011).

Mustafa, A., A. Butt, H.M. Tahir and M. Bilal: Susceptibility of wolf spider, Lycosa terrestris (Araneae: Lycosidae) to chlorpyrifos. Pakistan J. Zool., 43, 403-405 (2011).

NHB: National Horticulture Board, Indian Horticulture Database-2014, p. 302 (2015).

Pasqualini, E. and S. Civolani: Studies on side effects of some insecticides on aphid-feeding Coccinellidae in Emilia-Romagna fruit crops. Bulletin OILB/SROP, 26, 51-55 (2003).

Pedroso, E.C., G.A. Carvalho, M.I.S. Leite and D. T. Rezende: Selectivity of insecticides used in the cotton crop in regard to pupae and adults of the ladybird beetle, Cycloneda sanguinea (Linnaeus, 1763). Arquivos do Instituto Biologico Sao Paulo, 78, 537-544 (2011).

Ramya, S.L., T. Venkatesan, K.S. Murthy, S.K. Jalali and A. Varghese: Degradation of acephate by Enterobactor asburiae, Bacillus cereus and Pantoea agglomerans isolated from diamondback moth Plutella xylostella (L), a pest of cruciferous crops. J. Env. Bio., 37, 611-618 (2016).

Rudramuni, T., K.M.S. Reddy and C.T.A. Kumar: Evaluation of new systemic and contact insecticides against insect-pest complex of cotton. Crop Res., 42, 296-302 (2011).

Sakamoto, N., S. Saito, T. Hirose, M. Suzuki, S. Matsuo, K. Izumi, T.
Nagatomi, H. Ikegami, K. Umeda, K. Tsushima and N. Matsuo: The discovery of pyridalyl: A novel insecticidal agent for controlling lepidopterous pests. Pest Manag. Sci., 60, 25-34 (2004).

Satpathy, S., A. Kumar, A.K. Singh and P.K. Pandey: Chlorfenapyr: Anew molecule for diamondback moth (Plutella xylostella L.) managementin cabbage. Annals PI. Protec. Sci., 13, 88-90 (2005).

Seal, D.R., M. Ciomperlik, M.L. Richards and W. Klassen: Comparative effectiveness of chemical insecticides against the chilli thrips, Scirtothrips dorsalis Hood (Thysanoptera: Thripidae), on pepper and their compatibility with natural enemies. Crop Protec., 25, 949955 (2006).

Seetharamu, P., K.C. Punnaiah and M.S.V. Chalam: Safety of certain new insecticides to spiders and mirid bug population in rice ecosystem. J. Appl. Zool. Res., 17, 45-47 (2006).

Sontakke, P. P., G. T. Behere and D. M. Firake: Toxicity of pesticides against the diamond back moth Plutella xylostella (L.) (Lepidoptera: Plutellidae). Indian J. Ento. 78, 364-367 (2016).

Stark, J.D. and R.L. Crawford: Short-term effects of Margosan-O, a neem insecticide and chlorpyrifos on a spider community inhabiting turf grass. Biopest. Int., 1, 71-81(2005).

Suganthi, A., R. Jayakumar and S. Kuttalam: Field performance of pyridalyl 10 EC (S1812) against diamondback moth, Plutella xylostella L. (Lepidoptera; Yponomeutidae) on cabbage. J. Entom., 4, 60-63 (2007).

Talekar, N.S., J.C. Yang and S.T. Lee: Compilers of annotated Bibliography of Diamondback moth. Asian vegetable research and development centre, Shanhus, Taiwan, Vol. 2, pp. 199 (1990).

Uthamasamy, S., M. Kannan, K. Senguttuvan and S. A. Jayaprakash: Status, damage potential and management of diamondback moth, Plutella xylostella (L.) in Tamil Nadu, India. In: Proceedings of the Sixth International Workshop on Management of the Diamondback Moth and Other Crucifer Insect Pests, 21-25 March 2011 (Eds.: Srinivasan, R., Shelton, A. M., Collins, H. L.). Kasetsart University, Nakhon Pathom, Thailand. AVRDC - The World Vegetable Center, Taiwan, Publication No. 11-755, 321 p. (2011).

Vaseem, M., H. Singh, K. Kumar and M. Ali: Efficacy of newer insecticides against diamondback moth (Plutella xylostella Linn.) on cabbage under poly house condition. J. Exp. Zool. India, 17, 487-489 (2014).

Verma, A.M. and G.S. Sandhu: Chemical control of diamondback moth, Plutella maculipennis. J. Res. PAU. 5, 420-423 (1968).

Wang, Y., Y. Zhang, X. Wu, X. Lu, S. Lu and C.Yan: Effects of several pesticides on controlling Laodelphax striatellus and Cnaphalocrocis medinalis and killing spiders. ActaAgri. Shanghai, 25, 147-150 (2009).

Zalucki, M.P., A. Shabbir, R. Silva, D. Adamson, L. Shu-Sheng and M.J. Furlong: Estimating the economic cost of one of the world's major insect pests, Plutella xylostella (Lepidoptera: Plutellidae): Just how long is a piece of string? J. Econ. Entomol., 105, 1115-1129 (2012).

Zhang, X., J. He, C. Ye and Y. Xue: Monitoring on resistance of diamondback moth to abamectin and field control experiments in Yunnan, China. J. Huazhong Agri. Univ., 20, 426-430 (2001). 